\title{
Forgotten Personal Territories in the Traditional Iranian House: A Critical Reading
}

\author{
Mojtaba Valibeigi $^{1 \ltimes \bowtie}$, Sara Danay ${ }^{2}$, and Yegane Mokhtari ${ }^{3}$ \\ ${ }^{I}$ Assistant professor of Urban Planning Department, Buein Zahra Technical University, Qazvin, Iran \\ ${ }^{2}$ Master Student in Urban Design, Iran (Sara.danay94@gmail.com) \\ ${ }^{3}$ Researcher of Urban Planning Department, Buein Zahra Technical University, Qazvin, Iran \\ ${ }^{\circledR}$ Corresponding author’s Emails: Mojtaba.valibeigi@gmail.com; mojtaba.valibeigi@bzte.ac.ir
}

\begin{abstract}
This study aims to investigate the critical reading individual areas on traditional Iranian house. The method of this research is a deductive content analysis. This research has done in three steps; preparation, organization and final report or conclusion. First, in the preparation stage, the individual and family territory in Iranian culture is defined. In organization phase, by reviewing plans, maps and visual observations of Iranian houses, individual and family territories is classified. And in the last step, a conclusion from the situation of privacy and individuality in Iranian house is explained. It seems that family privacy has been the main function of traditional Iranian houses. Despite the spaces which could be as a personal and individuality territories, they didn't get this functions and individualism and individual values have been forgotten. Accordingly, individuality is not considered as a valuable being who needs his/her own territory, but his/her role is determined in relation to other people and values like veil, purity, cooperation and humility are given importance.
\end{abstract}

Keywords: Territoriality, Mahram Territories, Space Syntax, Personal Spaces, Traditional Iranian House

\section{INTRODUCTION}

Space is the hidden dimension of behavior and we make a relationship with each other by space (Hall et al., 1968). Researchers have considered several important cases by focusing on human space needs in living environment such as; space security, social relationship, readability, privacy, human dignity and identity (Aiello and Thompson, 1980). Most of these needs can only be taken by space syntax of living environment. A space syntax of residential environment needs spatial, functional, social hierarchies that has unbreakable relation with the concept of territory and territoriality (Wu et al., 2015; Koohsari et al., 2016; McCormack et al., 2019). Human and animals show territoriality behavior from different ways. Animals territoriality action based on biological principles and they use it as a way to occupy a spatial area. Although this action for humans is depended on norms and cultural criteria of society. Humans usually protect their territory by many of physical and chemical barriers or some marked symbols (Lang, 1994; Lang; Guilfoil, 1991). Every personalization and marking environment or protecting against of disturbance are as a territorial behavior. The concept of territory isn't only a spatial matter, but also is a social event. In fact, territory can be known as the position and the place of a community in space (Low, 2016; Bourdieu, 1996). The territory has basic role in human's life. And it may help one to organize their environment and get it personal or collective identity. According to Lang, the territory has 4 characteristics (Lang, 2006; Lang, 2014):

1- personalization and marking a place

2- supplying some functions from physiological needs till psychological.

3- The right to defend against disturbance

4- ownership sense and human rights to a place

Altman also provide a general category; that are first territory, second territory and public territory sequentially. He said "territory must be designed in such a way that people can recognize it's primary, secondary or public one (Altman, 1975; Altman, 1973). First territory: the primary territories are owned and used by just a person or a special group. Others also know that these people are the owner of this territory. The second territory has less exclusive role. $2^{\text {nd }}$ territories are available to the public and also are controlled by some invariant users. In fact, this concept refers to half personal and half public space of Alexander 
and interactive space of Layman and Scott (Wells et al., 2016). Public territory is temporary realm and almost is available for everyone and all of the people can use these places. This territory is named free area or public spaces. Chermayeff and Alexander presented a plan of communication realm and privacy from absolutely personal space until public spaces (Lawrence, 1984; Rossi, 2017). These space syntaxes consist: 1) personal syntax which related to one such as personal bedroom. 2) familiar syntax which related to primary group for example house is kind of it. 3) personal syntax of greater group which related to secondary groups for example, personal management from all of the residents of an apartment. 4) public syntax of greater group including intersection of greater group with public such as some spaces with limited control. 5) half public syntax of urban which can control with government or special institution like; banks, post offices, airports and townhall. 6) public syntax of urban with public ownership and complete accessibility for all of people such as parks and streets.

human territoriality is a set of attitudes and behaviors in and toward given physical areas and home is one of its expressions (Sebba and Churchman, 1983). Iranian houses were the result of cultural dominate and spiritual values and lifestyle. While a house is a place for resting and mental space and a shelter for the family and emotional needs for everyone. The concept of territory was so important in architecture of Iranian houses because a house isn't apart from its outside. Territorialities determined how to organize inside spaces of traditional houses from outside and public syntax. Imagining a range of private syntaxes till public in relations a place that's actually private is possible. But this range in architecture of Iranian houses focused more on the relation of households with others than the relations between each other. in the past, Personal values and freedom were neglected in Iran in various ways. One of these fields is Iranian architecture and urban planning that reflecting the culture of their society. One of the important aspects of critical readings of traditional architecture goes back to the position that human beings and human values have in them. And then it tries to combine individual values with traditions to create new architectural spaces that have both valuable cultural elements of the past and give more value to human beings. As Porteous (1976) has pointed out, at the core of the ethological concept of territoriality lies the place we call home. We personalize and defend this territory, and it in turn provides us with security, stimulation, and identity. It is a basic reference point for the structuring of space and the focus of spatial activity (Porteous, 1976).

Accordingly, the main purpose of the study is investigating private syntaxes in traditional Iranian house. This study consists of the following parts: at first the methodology of research is described, then an attempt is made to define the concept of personal and familiar syntaxes and their features. Familiar syntaxes are named as intimacy spaces. To the next part, different spaces of Iranian traditional houses are identified and analyzed. Finally, a critical review of private syntaxes of Iranian traditional house is done.

\section{MATERIALS AND METHODS}

This research is done with deductive content analysis method. The meaning of content in content analyzing is all kind of document which suggested the relations between people. According to this the paintings on the wall of caves, music, books, articles, handwritings, post cards, films, maps, direct and indirect observations and ... are included the content (Banks, 2018; Flick, 2018). Accordingly, content analysis as one of the methods of qualitative inquiries explicated and summarized the data. Researchers use deductive content analysis method when they want to test concepts, categories, theories or any conceptual structure in a new context. It is applied in qualitative research and the data collection method aims to reach data saturation (Kyngäs and Kaakinen, 2020). As this research wants to survey the territoriality and private syntaxes of the traditional Iranian house, a deductive content analysis has been used. From this way in this method, trying to infer and reveal hidden form in the documents, maps and observations. The qualitative analysis method consisted 3 steps; preparation, organization and conclusion.

In the preparation step, first an attempt is made to provide a definition of personal and family syntaxes based on theoretical foundations. Also, based on an interpretive and documentary study, the differences between individual-personal and intimacy- familiarity syntaxes in the Iranian cultural system is classified. In organizational step, first some traditional houses are determined as sample, according to this some traditional Iranian houses have been listed and seven architectural experts have chosen 15 of them which consist of Jowish housein Boushehr, Boroujerdi's house in Kashan, Bekheradi's hall of Esfahan, Zinat Ol Molouk's house of Shiraz, Ansari's house of Ormia, Masoudi's house in Tuyserkan, Bahmani's house of Zanjan, Samadian;s house of 
Hamadan, Nvab Vakil's house of Yazd, warlord Jalil Saravi's house in Sari, Sanaie Gajuri's house in Ardakan, Ghadaki's house in Tabriz, Modarres's house of Tehran, Tdayyon's house in Semnan, Yaghmaie's house in Shahroud. In this research exits samples of Samadian's house of Hamadan, Boroujerdis' and Tabatabaies' house in Kashan and Ansari's house in Esfahan.

Accordingly trying to answer these question: Do exist joint features in all of those houses for signifying personal syntaxes and familiar-intimacy syntaxes? What is the value and the situation of the personal syntaxes and familiar-intimacy syntaxes?

And in last step a conclusion of privacy and individualism is presented in traditional system of Iran. Which syntaxes did have more value? And which syntaxes and activities have been ignored? Is this pattern acceptable for contemporary?

\section{Intimacy spaces and Syntaxes in the Iranian traditional house}

Canter (1997) believed that the meaning of place is due to triple relationship between activities, concepts and physical features. Then for developing his theory, he points to four factors, including: functional differences, the aims of place, interaction scale and designing aspects. The functional differences are related to current activities in place. The aims of place and interaction scale are related to personal, social and cultural aspects and designing aspect is related to physical features (Gustafson, 2001; Sebba and Churchman, 1983; Cupers, 2017). So for investigating the syntax in traditional Iranian houses, we should consider the triple of activities, concepts and physical context which activities for what purposes take place in different spaces.

\section{Intimacy and close familiarity Space Syntax}

The syntax of intimacy in Islamic sexual jurisprudence is related to the word Mahram. A Mahram is a member of a person's family who is allowed to enter the house and is trustworthy. Thus, Mahram territory syntaxes brings intimacy, kinship and closeness (Majid et al., 2015; Aryanti, 2013). The meaning of intimacy in urban and architectural space is making a place in a way that has privacy from two aspects including physical and meaning. Having privacy in physical contexts are more focused on spatial security and in conceptual contexts give worth and reverence to architectural space. In such a way a person fells relaxed (Golshan, 2020; Memarian and Sadoughi, 2011). The house forms and its locating is determined according to religious believes. Usually interning to a house has some admission rites. Strangers must have entrance permission. In architecture, intimacy is formed by separating inner space from outsides. This separating and acquisition of space is because of intimacy that make home calm and comfortable for household and the passage of any spaces and the permission to enter each space is done according to the hierarchy. The houses that focus on intimacy and privacy have some features that are:

Narrow passages and often dead ends, terrace absence, not having any window to outside, existence of decorations inside the building and construction outside without façade along with high walls and fences for courtyard (Babaei et al., 2012; Habib et al., 2013; Hajian et al., 2020; Karimi and Hosseini, 2012).

\section{Personal Syntax}

Personal space is an especial behavioral environmental concept, Sommer (1969) believed that personal space is a protective, small and invisible territory which make a bubble between oneself and others (Sommer, 2002; Sommer, 1969). Personal private space is dynamic and variative. A person may feel annoyance because of infringement of others to this space. Personal specifications (personality, emotions, gender and age) along with physical environmental contexts like social norms and cultural rules affect personal space (Hecht et al., 2019; Wells et al., 2016).

One of the new concepts that seen on environmental psychology studies frequently is privacy. This concept implies human needs to be alone. Privacy is process that help a person to adjust his or her relationships with others and approach to introspection and it shows itself in house more than anywhere. Privacy doesn't mean avoidance and preventing to be with anyone but it's the existence of the right to choose spatial and behavioral hierarchy. it's a layer for social and geographical distancing (Steg et al., 2013; Gifford, 2007). Also, Westin (1968) explained privacy in four kinds: Isolation (being free from other vision), Proximity (close relationships and being free from the environment), Anonymity (being unknown among people), tolerance (using psychological barriers for controlling unknown disturbance) (Roberts and Gregor, 2017).

\section{Differences of personal and Mahram Syntaxes in islamic culture \\ The personal syntax has a spatial character and has a physical and material dimension; The personal syntax is not necessarily mean to be alone or stay away from others. solitude or individuality can be considered as a boundary}


through which a person can control and monitor interaction with others. But intimacy (Mahram) syntax indicates a human characteristic and has a spiritual and non-physical dimension. By analyzing the contents of personal and Mahram syntaxes, their comparison is presented in the following table:

Table 1. A compression between personal and mahram syntaxes

\begin{tabular}{|c|c|}
\hline Personal Syntax & Intimate Syntax \\
\hline $\begin{array}{l}\text { It shows the relationship } \\
\text { between a person and an } \\
\text { especial space. }\end{array}$ & $\begin{array}{l}\text { It's considered for } \\
\text { relationship between at least } \\
\text { two people with each other }\end{array}$ \\
\hline $\begin{array}{l}\text { One needs this syntax and } \\
\text { tries to reach the level of } \\
\text { desirability }\end{array}$ & $\begin{array}{l}\text { Efforts are made to protect it } \\
\text { from the influence of } \\
\text { strangers }\end{array}$ \\
\hline $\begin{array}{l}\text { In a place and with personal } \\
\text { criterions and needs and } \\
\text { existence situations are } \\
\text { defined. }\end{array}$ & $\begin{array}{l}\text { It's depended on culture and } \\
\text { custom and it's defined } \\
\text { without the need for time } \\
\text { and place }\end{array}$ \\
\hline $\begin{array}{l}\text { It's a relative matter and } \\
\text { depended on many } \\
\text { diversities }\end{array}$ & $\begin{array}{l}\text { It's less relative and religious } \\
\text { customs and beliefs are its } \\
\text { main variables. }\end{array}$ \\
\hline To have less stability & It has more stability \\
\hline To have reverence & $\begin{array}{l}\text { It has intimacy, holiness and } \\
\text { worthiness }\end{array}$ \\
\hline $\begin{array}{l}\text { It's the needs of all the } \\
\text { people }\end{array}$ & $\begin{array}{l}\text { Hierarchy and introversion } \\
\text { have main role in its making }\end{array}$ \\
\hline $\begin{array}{l}\text { It creates solitude and } \\
\text { loneliness }\end{array}$ & $\begin{array}{l}\text { It creates kinship and } \\
\text { closeness. }\end{array}$ \\
\hline $\begin{array}{l}\text { It's depended on personal } \\
\text { and environmental patterns }\end{array}$ & $\begin{array}{l}\text { It's affected by normative } \\
\text { and customary patterns }\end{array}$ \\
\hline $\begin{array}{l}\text { It's almost synonym to some } \\
\text { concepts like; solitude, } \\
\text { calmness and self- } \\
\text { contemplation }\end{array}$ & $\begin{array}{l}\text { It's almost synonym to veil, } \\
\text { privacy, zeal and chastity }\end{array}$ \\
\hline
\end{tabular}

\section{RESULTS AND DISCUSSION}

\section{Analysis of traditional Iranian houses and personal and Mahram Syntaxes}

Generally, there are 5syntaxes in each home: family, individual, welcome, service and courtyard syntaxes. These syntaxes have especial hierarchies in Iranian traditional houses. Traditional architecture of Iranian houses separated houses to two part: inside and outside. One of the features of traditional houses in most of the cities of Iran is their large area. The important parts of house in architecture of Iranian houses are: bench, entrance, vestibule, balcony, courtyard, hall, parlor and inside (Memarian and Brown, 2006; Memarian and Sadoughi, 2011; Nabavi and Ahmad, 2016).

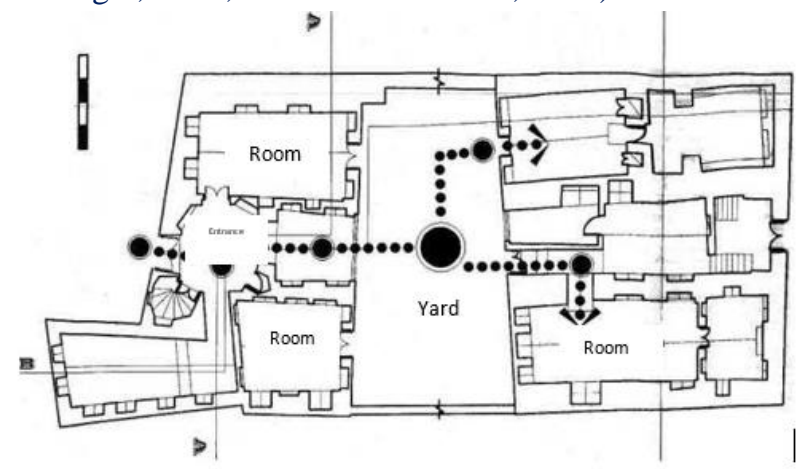

Figure 1. The plan of Samadian's house in Hmadan

According to the figure1 (The plan of Samadian's house in Hmadan) which is an example of a plan with Iranian traditional architecture, we can understand the concept of Mahram territories in its true meaning. As it's obvious from the building plan, the structure of Samadian's house is kind of houses that buildings are on both sides and the yard is between the buildings. Entrance leads to the yard. Samadian's house has three porches. Because of the privacy of these rooms, they don't have direct entrance from yard and a corridor is provided for each entrance. In general, the structure of traditional houses is meant to keep the private space for residents. But from past until now, the matter of personal spaces and individuality has always been neglected by designers and residents. In the past, large family didn't have enough space to dedicate an individual room for each person and family members had to share rooms at home, from this reason family members couldn't easily find a place to be alone.

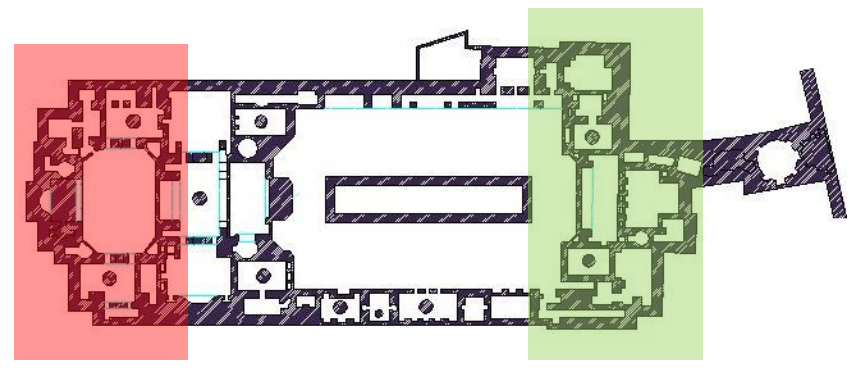

Figure 2: Boroujerdi's house in Kashan

In Figure 2 (Boroujerdi's house), the importance of the issue of Mahram territories in traditional Iranian architecture is obvious, separating the entrance path and also closing the corridor of view from outside to inside and creating a porch and frontage with platforms for guests waiting have been done in order to create privacy 
and Mahram space of the central courtyard. Boroujerdi's house has three entrance: the north entrance is the main, the west entrance is for religious and other ceremonies and the south entrance is for specials. The opening only leads to the courtyard and a complete wall without any window or view from outside shows the importance of this issue. In the architecture of Boroujerdi's house the space of the family members (red section) is completely designed separately from the guest's room (green section) and the central courtyard is located in center. Also, sometimes, two types of percussion (Figure 3) have been used at the traditional Iranian entrance to differentiate the sound until the landlord realizes that the guest is a man or a woman

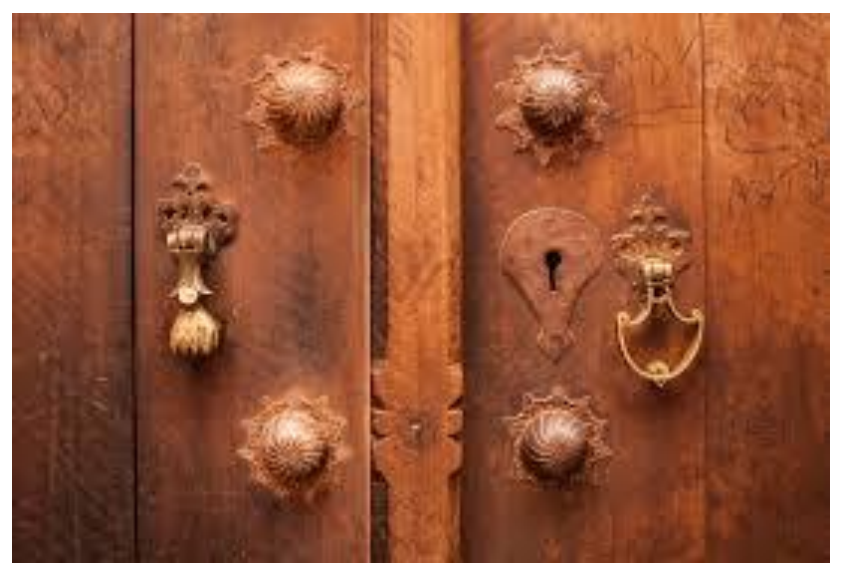

Figure 3. Two types of percussion at traditional Iranian entrance

It should be noted that Iranians from ancient times, according to their perception of home and family have shown tendency to introverted architecture. Basically, in forming of different spaces. Especially residential spaces, Iranian beliefs and specific issues of Iranian have been effective. One of these is Iranian self-esteem which has been effective in forming introverted house. One of the principle that effected vividly in forming Mahram territories in Iranian traditional building was the matter of introversion. Introversion is a concept that was a principle in Iranian architecture and with obvious presence in various ways is realized and seen (Nari Qomi and Momtahen, 2020; Raviz et al., 2015). Introversion itself origins from a territorial behavior. The society factor that causes introversion in the Iranian houses is the issue of protecting the inviolable privacy of the family away from the eyes of strangers. Being quiet, tendency to inner states and avoidance from pretention are the examples of being introversion in Iranian architecture, which is appear in the form of tortuous passages, mud and soil walls and simple buildings from outside but beautiful and detailed interior design (Razavizadeh, 2020; Safarian and Azar, 2020). Creating Mahram spaces induce introversion. Therefore, the character of introversion in Iranian traditional houses, in which the family has a special respect, has been completely compatible with the culture of society.

Pirnia (2005) in his book "Islamic architecture of Iran" has mentioned that in the researched in Iran from 6000 years ago, some houses can be seen with introvert design. In the houses that were built later, their residents didn't feel comfortable. The inside of the house was a place which a woman or a child lived. And it was being built in a way that housewife could work easily and no one could see her. In larger houses, private and public spaces separated deliberately by sections like: entrance, yard, porch, hallway, dooryard (Nejad and Abad, 2016).

\section{Mahram territories from outside to inside}

The peak of improvement in the principle of introversion in Iran can be consider in evolution of buildings with central courtyard. Buildings with courtyard in Iran are about eight thousands years old. And other buildings especially houses have taken about six thousand years to get central courtyard (Soflaei et al., 2017; Soleymanpour et al., 2015). As Pirnia (2005) said, in Iran they build a garden and a pool in the middle of the house and the rooms and halls wrapped around it like a closed embrace. There was no window or a hole in the house, or outside the wall. So that it could be seen from the outside, and the exterior was designed with arches, gates and congresses. And only had a gate or head board that considered opening.

Some features of Iranian introverted social architecture, the following can be mentioned:

1- Lack of direct visual connection among the interior spaces (private and semi-private) and outside spaces (public spaces).

2- Forming the spaces of the house with objects like: courtyard and porches. So that the openings lead into these objects.

In Iranian Islamic architecture, not everyone is allowed to disturb the privacy of the family, and the order of entrances to Iranian homes is as follows:

1- Most of the houses had entrances, the side platforms in front of the entrances were flat, which provided a suitable space for those who wanted to see the owner but did not need to enter the house.

2- The connection between the inside and the outside of the house is not as it is today, the visual privacy of the residents of the houses was completely secured and not every passer-by could enter the house. Even in the 
garden house, the yard or garden was large enough that it was impossible to see inside the house.

3- In the urban size, the alleys path had mazes that have a role of sight breaking and cause the private spaces along the private and public route.
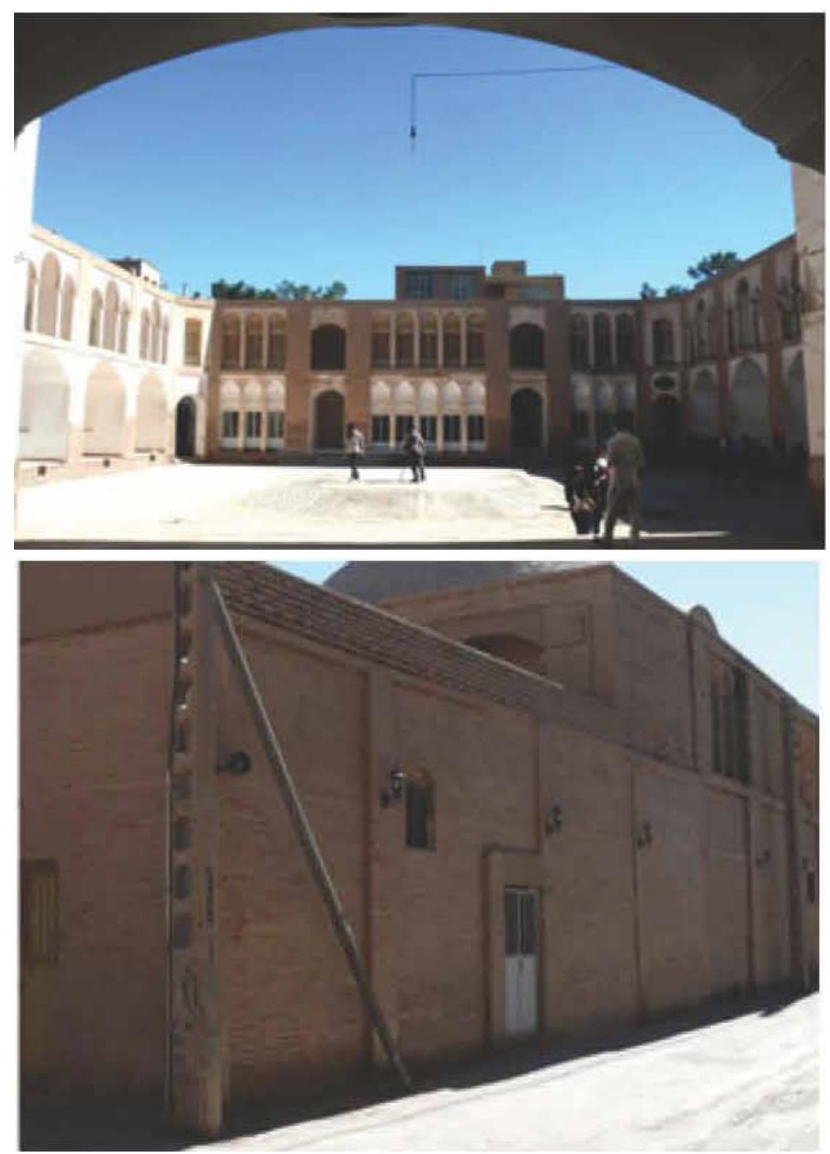

Figure 5: Distinction between the exterior and interior space of a house in Birjand

\section{Mahram territories from within}

Introversion and Iranian architect's attraction to the courtyards and pits of gardens, porches and pergolas that surround the naves and create attractive and familiar environments have long been the logic of Iranian architecture. Privacy is one of the concepts and elements that was effective in the design organization of architecture and urban planning, and the architect has used special strategies to reach this need. Spatial order (step-bystep movement from alley or street to the entrance space of the house and then private spaces) as well as the internal and external system operation is a way to provide the decent privacy.

In the Iranian house, there is three spaces: public, semi-public (semi-private) and private (Mahram territories).

\section{Public spaces}

Entrance: The entrance spaces themselves are part of the sequence of interconnected and related spaces of the whole house. For entering the building, the door and front of the house are both a barrier to entry and a place to greet semi-familiar guests. This space is used as a waiting entrance for newcomers, where the residents of the house make some usual compliments. Next to the entrance, there are platforms called Pakhoreh, which passers-by sometimes stop for a while to relieve their fatigue under shadow. Therefore, the location of two platforms on either side of the entrance is an expression of the value of communicating with neighbors and paying attention to citizenship rights. Individualize the door knockers of men and women on the doors proves the principle of secrecy. Muslim architects believe that the doors of houses in neighborhood units should not be opened facing or close to each other.

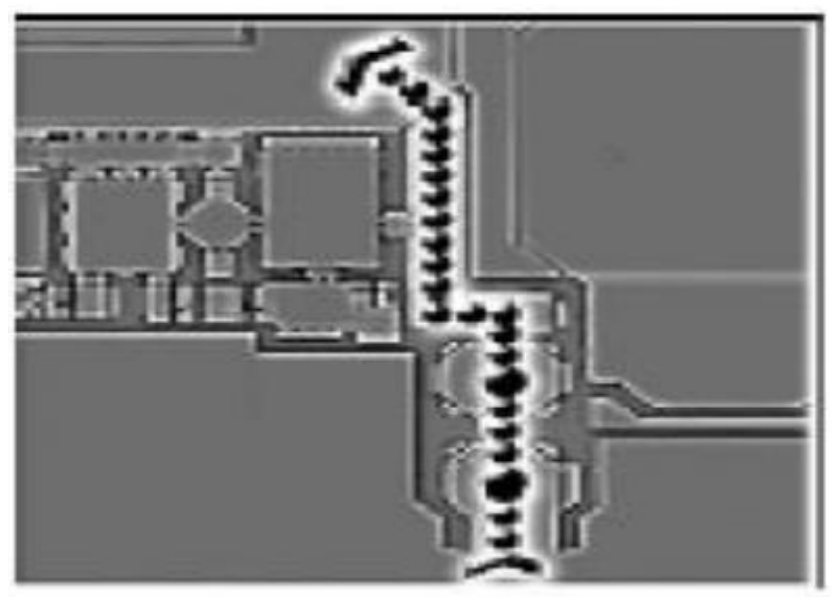

Figure 6, Diagram of how to enter Tabatabai's house.

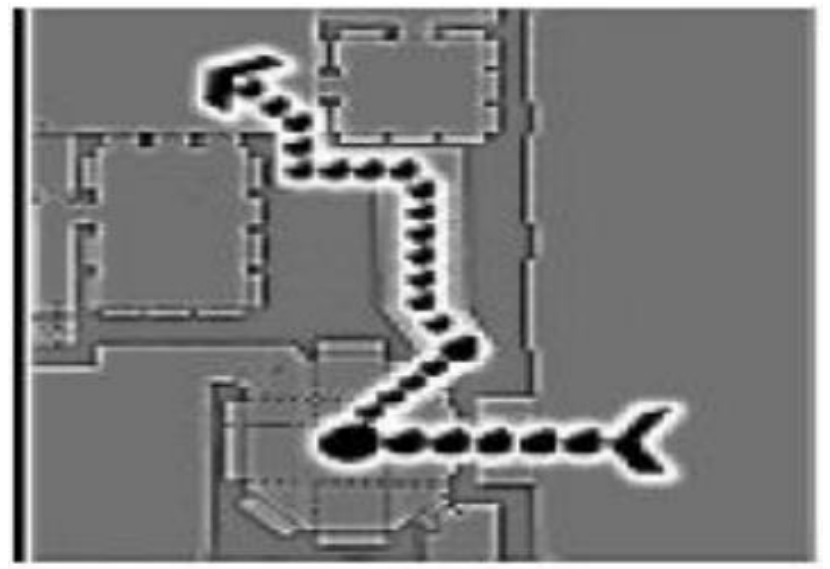

Figure 7. Diagram of how to enter Ansari's house in Isfahan. 
As shown in Figures 6 and 7, in the architecture of traditional houses such as Tabatabai houses, there is no view from the outside of the house to the inside, and the direct visual connection between the interior spaces and the outside space is completely cut off.
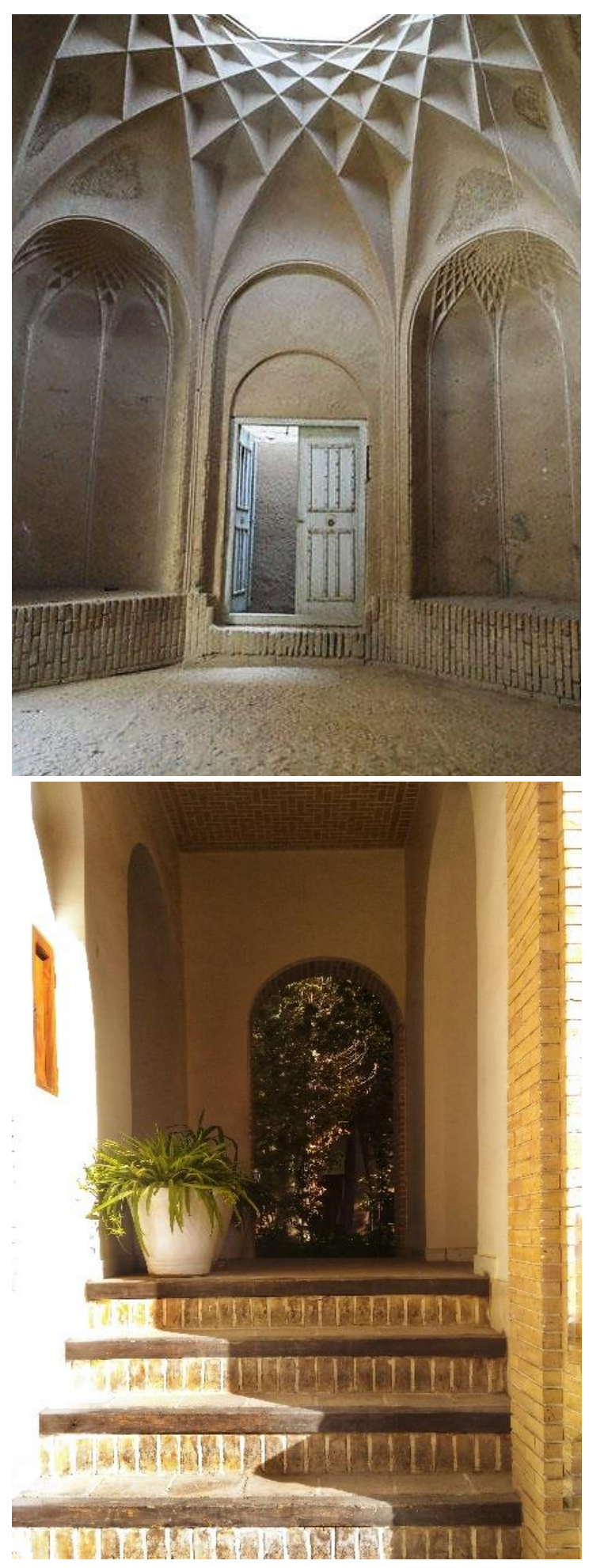

Figure 8. Toraab house's Hashti and Masoudieh's porch for entrance of parivate syntax
Porch and corridor: Porch or "karbas" is a space that has been designed and built in many types of entrance spaces. This space is often located right after the entrance space and one of its functions is to divide the entrance path into two or more directions. In some public buildings or houses, two or more paths led into the porch, each of which led to a specific space, including the interior of the building which is the courtyard. In buildings from which only one way out of the porch, the porch space did not function as a dividing space, but was used as a space for waiting and glorious entrance. Porches have regular geometric shapes with mostly low height and suitable for the entrance space (Nabavi and Ahmad, 2016).

Dedicated dead end or porch (semi-public space semi-private space) has the following features (see Fig.8):

- As the doors of the houses open to the space like a platform, porch or dead end, it creates the feeling of ownership and security.

- Residents can come together and make decisions by consulting and contacting each other without any interference in their private space.

- Access order avoids crowds and public commuting

- Semi-private - semi-public spaces that belong to several families, have led to the visiting and familiarity of residents with each other and as a result, residents are aware and careful about the area of their common space. Therefore, the porches have both an architectural function and are harmonized with the elegance of social life.

\section{Corridor}

Corridor is the simplest part of the entrance space, the most important function of which is to provide communication and access between two places. In some types of buildings, such as houses, baths, and in some cases mosques and schools, the extension and direction of the passage has been changed in the corridor. In this way, the issues of Mahram territory were solved by the corridor that led indirectly to the courtyard. The corridor is physically narrow and low width. Of course, the width of the corridors was determined according to the function of the building and the number of users. The average width of the corridors of mosques and large schools is between 2 and 3.5 meters and the width of the corridors of small houses is about one meter on average (Mamani et al., 2017).

\section{Semi-public spaces}

Balcony: The balcony can be considered as a space filter and a common part between open and closed spaces. Open or semi-public. In general, the balcony is used as a jointing space in Iranian architecture. 

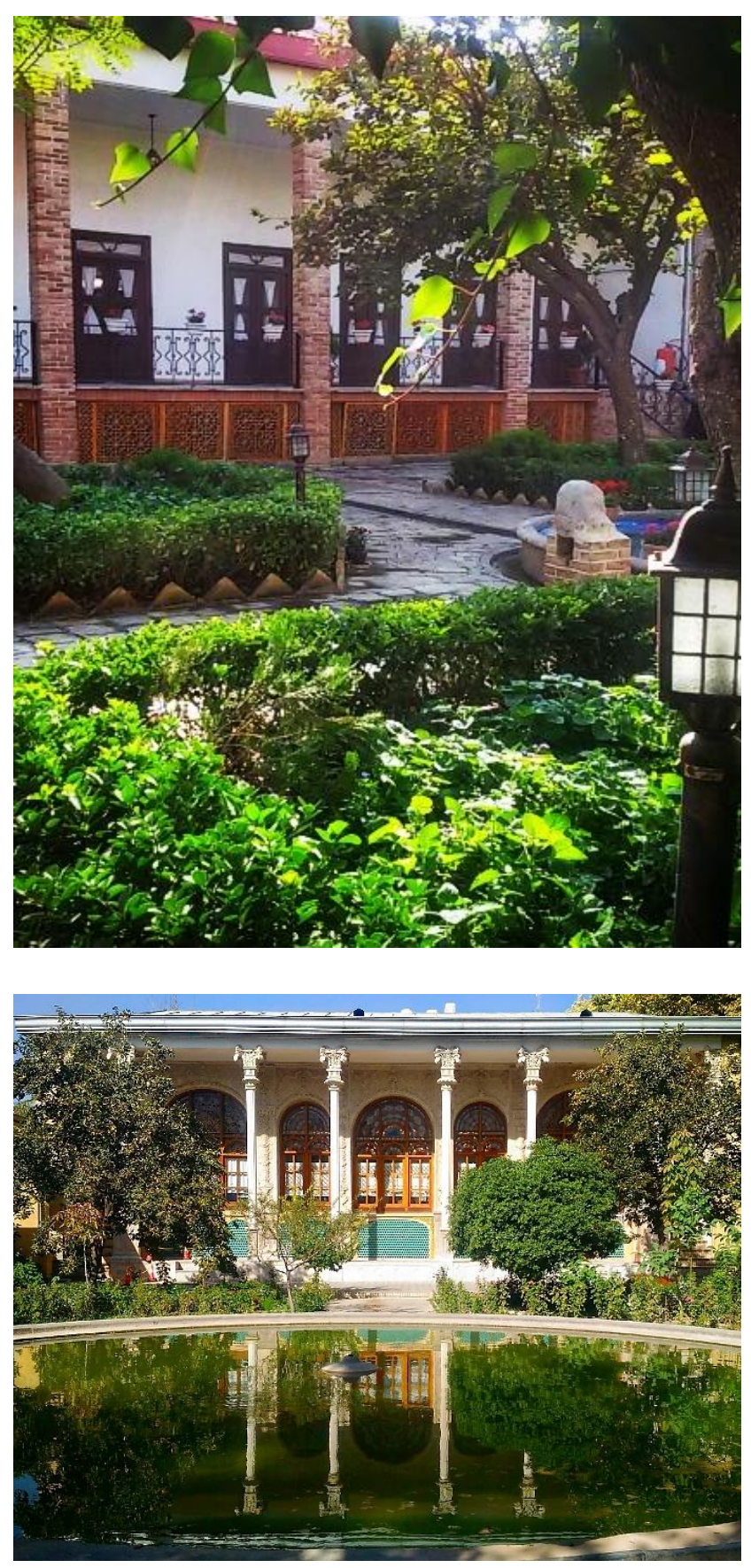

Yard: Housing is important in Islamic architecture due to direct connection with the private life and family life of the people. A Muslim's house should be the guardian of his family and should be built in accordance with the religion of Islam. In this regard, the main effect of Islam in the structure of a traditional house is introversion. Burckhardt (2009) describes the courtyard as an aspect of Muslims. He wrote in this case: Muslim houses receive light and air from their inner courtyards, not from the street.

\section{Mahram spaces}

Types of rooms: The most varied and widely used part of the house has been the interior so that the residents of the house do not feel tired and repetitive. The rooms in a traditional house were arranged around the yard according to their importance and use. Summer rooms were usually located on the south side to be less exposed to the sun during summer days, and winter rooms were located in front of the summer rooms and exactly on the side that gets the most sun during the day. Other spaces such as storage, kitchen and stables were located in the second row and behind the rooms (Mamani et al., 2017)

Service space: A backyard was a type of yard that usually had a secondary and service aspect and was designed and built in a part of the house to provide light and ventilation or as an open space for services, and its position and shape were very diverse. Usually, service areas, including the kitchen or bathroom, which should have been built away from the privacy of the house, have access to these backyards, and while providing services, it is responsible for staying away from public view and maintaining Mahram territories for the home's personal affairs.

\section{CONCLUSION}

According to the Islamic-Iranian culture, a space can be considered a Mahram territory that physically has a social concept and it is considered at least in a relationship between two people and is different from personal spaces. The results show that despite the potential of those houses to create personal spaces and territories, they do not pay attention to these spaces. And the lack of completely personal spaces are very obvious in traditional Iranian houses.

Since ancient times, Iranians have shown a tendency towards an introverted architecture according to their perception of home and family. Family privacy has been the main function of traditional Iranian houses. We see values such as Hijab (veil), cooperation, purity, contentment, God-centeredness and obedience and humility. Therefore, the most private spaces are interactive spaces such as Mahram territories. This kind of territory is not a place that one can be alone. Rather, it is an interactive place for two or more people who feel comfortable with each other semantically, and in physically, it creates security for them. Therefore, in the past privacy was defined for a set of persons and the houses spaces did not belong to a specific person. The room where they sleep was the same space as the table for eating. Every person wants to make a new and unique concept for his/her life with different facilities, tools, technologies and situations that live in and he/she should 
find these facilities in his/her home. Changing the values from social values to personal values, and becoming freer the human subject from natural and social limitations cause a challenge to the meaning and power of individual subjectivity and agency. It seems that Iranian traditional houses can be the patterns and models of designing contemporary when they are redefined in a combination of modern and traditional elements. By valuing personal territories in combination with the territories of Mahram, while maintaining the peace and security of the inhabitants, they also cause personal growth. Having a home means gaining "privacy". Privacy is a place where man can have peace and live and behave as he and his individuality demand. Privacy is a place where human dignity is respected. Home is the "cultural space" that separates us from the other and at the same time makes our life and coexistence with others possible.

The concepts of privacy and individuality are cultural concepts that differ from one culture to another. In societies where individualism is more developed and individualistic values prevail, the personal territory in both its spatial and social sense is one of the key concepts of social life. In such cultures, the architecture of the house is such that each member of the house can have their own "privacy" inside the house. Therefore, the most important issue is not the area or form of the house, but the way the space is distributed and divided. Conversely, in societies and cultures where Iranian tradition values prevail, the concept of privacy is different, and the cultural function of the home is above all to preserve collective values. In Iranian culture, the home is a place to express traditional religious values and preserve the family. In Iran culture, the concepts of home and family have a common root. But in this culture, there is no syntaxes between members living in the house. Hence, the children of each house do not have their own private room.

Traditional houses had gender function and unequal concept. The house, like other social categories, was masculine because the basis of the house was based on the comfort and well-being of men and under the management and authority of the father and the protection of women. Women played the role of housewives in the traditional division of labor. One of the main functions of the house has been to protect women, a role that clothing and veils also play in a different way. From this point of view, it can be said that the gender function of the traditional house has been to create privacy for women and protect her by hiding her. And the house played the role of creating a distance (a veil) between women and the outsider and did not care about individual values and individuality.

\section{Conflict of interest statement}

I hereby states that, there is no conflict of interest whatsoever with any third party.

\section{References}

Aiello JR and Thompson DE (1980). Personal space, crowding, and spatial behavior in a cultural context. Environment and culture. Springer, 107-178. https://doi.org/10.1007/978-1-4899-0451-5_5

Altman I (1973). Reciprocity of Interpersonal Exchange1. Journal for the Theory of Social Behaviour 3(2): 249-261. DOI: https://psycnet.apa.org/doi/10.1111/j.1468-5914.1973.tb00325.x

Altman I (1975). The Environment and Social Behavior: Privacy, Personal Space, Territory, and Crowding. https://eric.ed.gov/?id=ed131515

Aryanti T (2013). Breaking the wall, preserving the Barrier: gender, space, and power in contemporary mosque architecture in Yogyakarta, Indonesia. University of Illinois at Urbana-Champaign. http://hdl.handle.net/2142/45570

Babaei S, Fazeli N and Ghasemzadeh B (2012). Sustainable strategies in Iranian houses. Life Science Journal 9(3). http://www.lifesciencesite.com/lsj/life0903/373_11251life0903_25 76_2580.pdf

Banks $\bar{M}$ (2018). Using visual data in qualitative research: Sage. https://scholar.google.com/scholar?cluster=9157333186666321935 $\&$ hl=en\&as_sdt $=2005 \&$ sciodt $=0,5$

Bourdieu P (1996). Physical space, social space and habitus. Vilhelm Aubert Memorial lecture, Report 10: 87-101. https://archives.library.illinois.edu/erec/University\%20Archives/2401001/Pro duction_website/pages/StewardingExcellence/Physical\%20Space,\%20Social $\% 20$ Space $\% 20$ and $\% 20$ Habitus.pdf

Burckhardt T (2009). Art of Islam: language and meaning: World Wisdom,

Inc. https://scholar.google.com/scholar?cluster $=8318602048590013220$ $\&$ hl=en\&as_sdt $=2005 \&$ sciodt $=0,5$

Canter D (1997). The facets of place. Toward the integration of theory, methods, research, and utilization. Springer, 109-147. http://eprints.hud.ac.uk/id/eprint/9226/1/

Cupers K (2017). Human territoriality and the downfall of public housing. Public Culture 29(1 (81)): 165-190. https://scholar.google.com/scholar?cluster=1118174578736143426 $3 \& \mathrm{hl}=$ en\&as_sdt $=2005 \&$ sciodt $=0,5$

Flick U (2018). Designing qualitative research: Sage. https://scholar.google.com/scholar?cluster $=565578096448907202 \&$ $\mathrm{hl}=$ en\&as_sdt $=2005 \&$ sciodt $=0,5$

Gifford R (2007). Environmental psychology: Principles and practice: Optimal books Colville, WA. https://scholar.google.com/scholar?cluster=6278374041741532480 $\& \mathrm{hl}=$ en\&as_sdt $=2005 \&$ sciodt $=0,5$

Golshan HH (2020). Exploring Traditional Iranian house and culture using Space Syntax theory and methods, Case Study: Brojerdiha Mansion, Kashan, IRAN. Creative City Design. http://crcd.sinaweb.net/article_676312.html

Guilfoil JK (1991). Reviews: John Lang's Creating Architectural Theory. Journal of Social Theory in Art Education 11(1): 163-166. https://scholar.google.com/scholar?cluster=7351314796402029319 $\&$ hl=en\&as_sdt $=2005 \&$ sciodt $=0,5$

Gustafson P (2001). Meanings of place: Everyday experience and theoretical conceptualizations. Journal of environmental $\begin{array}{lll}\text { psychology } & 21(1): & 5-16 .\end{array}$ https://doi.org/10.1006/jevp.2000.0185

Habib F, Alborzi F and Etessam I (2013). Light processing in iranian houses, manifestation of meanings and concepts. International Journal of Architecture and Urban Development 3(3): 11-20. https://www.sid.ir/en/journal/ViewPaper.aspx?id=352363

Hajian M, Alitajer S and Mahdavinejad M (2020). The Influence of Courtyard on the Formation of Iranian Traditional Houses Configuration in Kashan. Armanshahr Architecture \& Urban Development 13(30): 43-55. DOI: https://dx.doi.org/10.22034/aaud.2020.133667.1554 
Hall ET, Birdwhistell RL, Bock B, Bohannan P, Diebold Jr AR, Durbin M, Edmonson MS, Fischer J, Hymes D and Kimball ST (1968). Proxemics [and comments and replies]. Current anthropology 9(2/3): 83-108. DOI: https://doi.org/10.1086/200975

Hecht H, Welsch R, Viehoff J and Longo MR (2019). The shape of personal space. Acta psychologica 193: 113-122. DOI: https://doi.org/10.1016/j.actpsy.2018.12.009

Karimi AZ and Hosseini B (2012). The Influence Of Iranian Islamic Architecture On Traditional Houses Of Kashan". Second International Conference, Mukogowa Women's Univ, Nishinomiya, Japan. https://www.mukogawau.ac.jp/ iasu2012/pdf/iaSU2012_Proceedings_204.pdf

Koohsari MJ, Owen N, Cerin E, Giles-Corti B and Sugiyama T (2016). Walkability and walking for transport: characterizing the built environment using space syntax. International Journal of Behavioral Nutrition and Physical Activity 13(1): 1-9. https://ijbnpa.biomedcentral.com/articles/10.1186/s12966-0160448-9/metrics

Kyngäs H and Kaakinen P (2020). Deductive Content Analysis. In: Kyngäs H, Mikkonen K and Kääriäinen M (eds) The Application of Content Analysis in Nursing Science Research. Cham: Springer International Publishing, 23-30. http://dl1.tarjomac.ir/nursingebooks/TPC202203.pdf

Lang J. designing for personal security: privacy issues and concerns in urban design. https://scholar.google.com/scholar?hl=en\&as_sdt=0\%2C5\&q=Lang+J+DESIGNING+FO R+PERSONAL+SECURITY\%3A+PRIVACY+ISSUES+AND+CONCERNS+IN+URBA N+DESIGN.\&btnG=

Lang J (1994). Urban design: the American experience: John Wiley \& Sons.

https://scholar.google.com/scholar?cluster=2589671767135530850 $\&$ hl $=$ en\&as_sdt $=2005 \&$ sciodt $=0,5$

Lang J (2006). Urban design: Routledge. https://scholar.google.com/scholar?cluster=1415015175257320259 $7 \& \mathrm{hl}=\mathrm{en} \& \mathrm{as} \_\mathrm{sdt}=2005 \&$ sciodt $=0,5$

Lang J (2014). Comments on 'the place shaping continuum: A theory of urban design process'. Journal of Urban Design 19(1): 41-43. https://doi.org/10.1080/13574809.2014.854681

Lawrence RJ (1984). Transition spaces and dwelling design. Journal of architectural and Planning Research: 261-271. https://www.jstor.org/stable/43028706

Low S (2016). Spatializing culture: The ethnography of space and place: Taylor \& Francis. https://scholar.google.com/scholar?cluster=1726938431623010527 $3 \& \mathrm{hl}=\mathrm{en} \& \mathrm{as} \_s d \mathrm{t}=2005 \&$ sciodt $=0,5$

Majid NHA, Denan Z, Abdullah FH and Noor MSM (2015). Shariah compliance hospitality building design: A Malay Muslim oriented architecture. Procedia-Social and Behavioral Sciences 201: 136145. DOI: https://doi.org/10.1016/j.sbspro.2015.08.159

Mamani H, Haghir S and Barati N (2017). The Early Islamic Centuries: a Criterion for the Impact of Religious Beliefs on Architecture and Decoration of Iran. Journal of History Culture and Art Research 5(4): 321-329. DOI: https://doi.org/10.7596/taksad.v5i4.607

McCormack GR, Koohsari MJ, Turley L, Nakaya T, Shibata A, Ishii K, Yasunaga A and Oka K (2019). Evidence for urban design and public health policy and practice: Space syntax metrics and neighborhood walking. Health \& Place: 102277. doi: https://doi.org/10.1016/j.healthplace.2019.102277

Memarian G and Brown F (2006). The shared characteristics of Iranian and Arab courtyard houses. Courtyard housing: Past, present and future: 21-30. https://www.taylorfrancis.com/chapters/edit/10.4324/978020364672412/shared-characteristics-iranian-arab-courtyard-houses-gholamhossein-memarian-frankbrown

Memarian G and Sadoughi A (2011). Application of access graphs and home culture: examining factors relative to climate and privacy in Iranian houses. Scientific Research and Essays 6(30): 6350-6363. doi: https://doi.org/10.5897/SRE11.1620

Nabavi F and Ahmad Y (2016). Is there any geometrical golden ratio in traditional Iranian courtyard houses? ArchNet-IJAR: International Journal of Architectural Research 10(1): 143. https://www.proquest.com/openview/e52c80f4ac51bbb142827b8b583fe8f9/1 ?pq-origsite $=$ gscholar\&cbl=276235
Nari Qomi Mo and Momtahen M (2020). The Continuity of the Extended Family Structure within Contemporary Single-Family Houses Case Study: Afghan Immigrant Households in Iran. Journal of Iranian Architecture Studies 1(16): 133-151. DOI: http://dx.doi.org/10.22052/1.16.133

Nejad JM and Abad ASH (2016). Expressions of islamic ideas and foundations in the noble iranian-islamic architecture,(Case study: Khan School in Shiraz). Journal of Fundamental and Applied Sciences 8(3): 1115-1131. DOI: https://doi.org/10.4314/jfas.v8i3.25

Pirnia MK (2005). Introduction to Islamic architecture of Iran. Tehran: Soroosh

Danesh. https://scholar.google.com/scholar?hl=en\&as_sdt=0\%2C5\&q=Pirnia+MK+\%282005\% 29 . +Introduction+to+Islamic+architecture+of+Iran.+Tehran\%3A+Soroosh+Danesh.\&btnG=

Porteous JD (1976). Home: The territorial core. Geographical Review: 383-390. DOI: https://doi.org/10.2307/213649

Raviz SRH, Eteghad AN, Guardiola EU and Aira AA (2015). Iranian courtyard housing: The role of social and cultural patterns to reach the spatial formation in the light of an accentuated privacy. ACE: architecture, city and environment. Vol. 10, Núm. 29 https://raco.cat/index.php/ACE/article/view/301293

Razavizadeh AS (2020). Representation of Sustainable Archy Type in the Architecture of the Past and Present of the Iranian House (Kashan and Yazd Houses, Qajar and Contemporary Period). Iran University of Science \& Technology 8(2): 61-75. http://jria.iust.ac.ir/article-11302-en.html

Roberts JM and Gregor T (2017). Privacy: A cultural view. Privacy and Personality. $\quad$ Routledge, 199-225. https://scholar.google.com/scholar?cluster=14943177208558939274\&hl=en \&as_sdt $=2005 \&$ sciodt $=0,5$

Rossi U (2017). The Street As a Living Space. L'architettura delle cittàThe Journal of the Scientific Society Ludovico Quaroni 7(10). http://www.architetturadellecitta.it/index.php/adc/article/view/169

Safarian P and Azar A (2020). A survey of the effect of cultural roots of society on design of house architecture (Case study: Traditional culture of Iran society, Iranian-Islamic houses). kurmanj. 2020; 2 (3) :1-7 URL: http://kurmanj.srpub.org/article-2-32-en.html

Sebba R and Churchman A (1983). Territories and territoriality in the home. Environment and Behavior 15(2): 191-210. https://doi.org/10.1177\%2F0013916583152004

Soflaei F, Shokouhian M and Zhu W (2017). Socio-environmental sustainability in traditional courtyard houses of Iran and China. Renewable and Sustainable Energy Reviews 69: 1147-1169. DOI: https://doi.org/10.1016/j.rser.2016.09.130

Soleymanpour R, Parsaee N and Banaei M (2015). Climate comfort comparison of vernacular and contemporary houses of Iran. Procedia-Social and Behavioral Sciences 201: 49-61. DOI: https://doi.org/10.1016/j.sbspro.2015.08.118

Sommer R (1969). Personal Space. The Behavioral Basis of Design. URL: https://eric.ed.gov/?id=ED036112

Sommer R (2002). Personal space in a digital age. Handbook of environmental psychology: 647-660. https://scholar.google.com/scholar?cluster=2046992396767180613 $\&$ hl=en\&as_sdt $=2005 \&$ sciodt $=0,5$

Steg LE, Van Den Berg AE and De Groot JI (2013). Environmental psychology: An introduction: BPS Blackwell. https://pure.rug.n1/ws/portalfiles/portal/168768507/Environmental_ Psychology_An_Introduction_1_Environmental_psychology_Histo ry_scope_and_methods_.pdf

Wells NM, Evans GW and Cheek KA (2016). Environmental psychology. Environmental health: From global to local 203. https://scholar.google.com/scholar?cluster=1454670662212889420 $9 \& \mathrm{hl}=\mathrm{en} \&$ as_sdt $=2005 \&$ sciodt $=0,5$

Westin AF (1968). Privacy and freedom. Washington and Lee Law Review 25(1): 166 https://scholarlycommons.law.wlu.edu/cgi/viewcontent.cgi?article= 3659\&context=wlulr

Wu L, Liu X, Ye X, Leipnik M, Lee J and Zhu X (2015). Permeability, space syntax, and the patterning of residential burglaries in urban China. Applied Geography 60: 261-265. https://doi.org/10.1016/j.apgeog.2014.12.001 